University of Chicago Law School

Chicago Unbound

Journal Articles

Faculty Scholarship

2001

\title{
'In Such Manner as the Legislature Thereof May Direct': The Outcome in Bush v Gore Defended
}

Richard A. Epstein

Follow this and additional works at: https://chicagounbound.uchicago.edu/journal_articles

Part of the Law Commons

\section{Recommended Citation}

Richard A. Epstein, "'In Such Manner as the Legislature Thereof May Direct': The Outcome in Bush v Gore Defended," 68 University of Chicago Law Review 613 (2001).

This Article is brought to you for free and open access by the Faculty Scholarship at Chicago Unbound. It has been accepted for inclusion in Journal Articles by an authorized administrator of Chicago Unbound. For more information, please contact unbound@law.uchicago.edu. 


\section{The University of Chicago Law Review}

Volume 68

Summer 2001

Number 3

(C) 2001 by The University of Chicago

\section{"In such Manner as the Legislature Thereof May Direct": The Outcome in Bush v Gore Defended}

Richard A. Epstein $\dagger$

For most American citizens, interest in the presidential election campaign of 2000 ended when the Supreme Court in Bush v Gore refused to allow any further recount of the Florida votes. After a short flurry of heated debate over the soundness of the decision, the nation buckled down to business as usual. The attention of the media was, to say the least, short-lived. No longer did reporters seek out law professors to dissect past legal maneuvers and to predict future ones. Political attention quickly turned to John Ashcroft, Linda Chavez, and Gale Norton-all controversial Bush nominees for key cabinet positions. The public seems not to be composed of legal purists. It expected something ugly, and in a succession of divided opinions from the Florida and United States Supreme Courts, it got it. But resilience is the mark of a nation that quickly shrugged off one bruising legal and political struggle only to begin a second, and a third, and ....

Constitutional law professors form a different breed, with longer memories and deeper resentments. Although the short-term issue of who counts as president has been resolved, letters and articles have voiced with varying degrees of indignation a common theme that the legitimacy of the Court has been effectively called into question by its political coup d'état. ${ }^{2}$ The Court's decision in Bush v Gore has been

$\dagger$ James Parker Hall Distinguished Service Professor of Law, The University of Chicago; Peter and Kristin Bedford Senior Fellow, The Hoover Institution.

$121 \mathrm{~S} \mathrm{Ct} 525$ (2000) (per curiam).

2 See, for example, Jeffrey Rosen, Disgrace, New Republic 18 (Dec 25, 2000) (arguing that the majority in Bush v Gore "have ... made it impossible for citizens of the United States to sustain any kind of faith in the rule of law"). 
regarded in many quarters as a travesty of constitutional law incapable of rational defense. Recently, for example, 585 law professors have signed a public letter attacking a conservative and mean-spirited Court for its devious and hypocritical judicial activism. ${ }^{3}$ It is difficult to assess the potential influence of these harsh condemnations and dire predictions on public opinion and the political process. But, as the battles over the Bork and Thomas nominations show, old wounds are easily reopened in confirmation hearings of presidential Supreme Court nominees.

In this case, I think that overheated rhetoric has led to overstated charges. It is for this reason that I shall mount a qualified rear-guard defense of the outcome in Bush v Gore. I shall not do so on the equal protection grounds that carried the day with the five conservative justices who voted to end the recount. Quite simply, I regard that argument as a confused nonstarter at best, which deserves much of the scorn that has been heaped upon it. The same harsh judgment, however, cannot be made of the alternative ground for decision that was championed by Chief Justice Rehnquist in a concurring opinion joined only by Justices Scalia and Thomas, which would have overturned the decision of the Florida Supreme Court on the ground that its rulings ran afoul of Article II, Section 1, Clause 2 of the U.S. Constitution, which provides that "Each State shall appoint, in such Manner as the Legislature Thereof May Direct," the electors for the offices of President and Vice President. Unlike the equal protection phase of the case, any evaluation of this claim requires us to analyze the decision of the United States Supreme Court in relation to the two decisions of the Florida Supreme Court in the post-election period. ${ }^{4}$ Part I discusses the equal protection arguments. Part II is devoted to the less conspicuous but more potent Article II argument.

\section{The Equal Protection Claim}

Any equal protection challenge to the Florida recount procedure quickly runs into insurmountable difficulties. The initial foray of the U.S. Supreme Court's per curiam opinion was to note the start-andstop quality of the recount procedures throughout the state. ${ }^{5}$ There was wide variation in standards across counties that used the paper

3 See Dave Zweifel, Court Decision Still Rankles Law Profs, Cap Times 6A (Jan 24, 2001) (reprinting text of ad).

4 Gore v Harris, 772 S2d 1243 (Fla Dec 8, 2000) (overturning trial judge; ordering immediate statewide recount of undervotes), revd and remd as, Bush v Gore, $121 \mathrm{~S} \mathrm{Ct} 525$; Palm Beach County Canvassing Board v Harris, 772 S2d 1220 (Fla Nov 21, 2000) (ruling that the Secretary of State had to take late-submitted totals from canvassing boards), vacd and remd as, Bush v Palm Beach County Canvassing Board,121 S Ct 471 (2000) (per curiam).

5 See Bush v Gore, $121 \mathrm{~S} \mathrm{Ct} 525$. 
ballots with their now-infamous chads. There were also wide variations in standards over time within a single county: Palm Beach, for example, had several different standards on the counting of chads, which veered from narrow to broad and back again. There were also allegations that the Democrats (and doubtless the Republicans) placed pressure on the canvassing boards in Broward, Palm Beach, and Miami-Dade Counties to expand the definition of what votes could be counted. ${ }^{7}$ None of the variations and switches that took place in time could be easily justified by differences in local equipment or local practices. There is also little doubt that uniformity in election procedures is highly desirable as a minimum, noncontroversial condition for procedural fairness. Indeed, Florida law charges the Secretary of State, as its chief election officer, with the responsibility to "[o]btain and maintain uniformity in the application, operation and interpretation of the election laws."

Even against this troublesome backdrop, the equal protection claim runs into two serious challenges, one substantive and the other remedial. First, why does the inconsistent administration of the Florida election laws amount to a violation of the Equal Protection Clause? Second, why, if such is the case, was it appropriate or necessary to end the recount?

As to the first, there is an obvious gulf between the cases cited by the Supreme Court majority and the unfortunate electoral situation as it developed in Florida. Harper v Virginia Board of Elections ${ }^{9}$ struck down a poll tax of up to $\$ 1.50$ on the ground that it amounted to an implicit discrimination on account of wealth that bore no relation to voting qualifications proper. ${ }^{10}$ To be sure, no one can doubt that any individual who cannot pay the tax is excluded from the polls. This freeform decision, which self-consciously sought to distance itself from Lochner v New York," was itself something of a stretch under classical equal protection law given that a poll tax is facially neutral and, unlike literacy tests, can be applied in a mechanical way that eliminates the dangers of political discretion. At root it looks as though Harper rests on the proposition that voting rights are so fundamental that they

6 See id at 531.

7 See Don Van Natta, Jr. and David Barstow, Counting the Vote: The Canvassing Boards: Elections Officials Focus of Lobbying from Both Camps, NY Times A1 (Nov 17, 2000) (reporting on pressure exerted on canvassing boards during the recount fight).

8 Fla Stat Ann $\S 97.012$ (West 2000).

9383 US 663 (1966).

$10 \quad$ Id at 666.

11198 US 45 (1905) (ruling that a maximum hour law for bakers violated the Due Process Clause), noted in Harper, 383 US at 669. 
cannot be abridged on account of wealth. Be that as it may, Harper has scant relevance to the probity of Florida's recount procedures. It is one thing to find a serious affront to equal protection from a wealth test that is uniform in its application but disparate in its impact. It is quite another to find an equal protection violation in a process that does not take into account wealth (or for that matter, race) in deciding what counts as a valid vote. In a word, the Florida scheme is devoid of any suspect classification needed to trigger the equal protection analysis.

Likewise, the per curiam citation to Reynolds $v \operatorname{Sims}^{12}$ also runs far afield. That case dealt with the refusal of state legislatures to reapportion themselves, in ways that perpetuated massive differences in the size of legislative districts. ${ }^{13}$ The obvious imbalance is that all individuals who reside in populous counties systematically have much less political influence than their peers who reside in less populous counties. It is possible therefore to identify unambiguously the winners and losers from the state practice, and to demand in principle at least some justification for imbalances consciously perpetuated by the refusal of the dominant legislative coalition to initiate electoral reforms that would necessarily cut into its own power.

That situation bears scant resemblance to the Bush versus Gore dispute, in which all Florida voters, no matter where they lived, had equal say in the outcome of the election. No one in Florida practiced a conscious manipulation of the voting standard that necessarily skews the outcome in favor of one region, or even one group. To see why, start with the simple but realistic assumption that the election features only two candidates and that the winner is selected by a simple majority vote, with one vote per person. Under these circumstances it is sensible to treat the vote as though it were a share in some corporate enterprise, which is run by the party that commands just over 50 percent of the vote. On this view, Harper makes it impossible to exclude shareholders who cannot pay some minimum voting fee. Reynolds in turn holds that one share of stock cannot have ten votes while another share of stock only has one.

Bush v Gore, however, does not fall into either of these simple patterns of electoral skewing for there is no conscious form of ex ante discrimination. From the ex ante perspective no one can identify the determinate class of individuals who benefit from or are burdened by the choice of this or that standard for counting ballots. It is not as though one standard was used for Gore voters and another for Bush

12377 US 533 (1964) (upholding district court orders to reapportion both houses of the Alabama legislature, noting that the failure to do so violated the Equal Protection Clause).

13 Id at $561-66$. 
voters. It is thus no surprise that the per curiam opinion was unable to explain why this asserted equal protection violation worked to Bush's disadvantage. Here the key feature of any equal protection challenge is that it takes no position on the proper standard for counting votes. Rather, like any argument from distributive justice, it merely argues that like cases (or votes) should be treated alike, but remains agnostic on how any-indeed all-of these cases (or votes) ought to be treated. ${ }^{14}$ Hence, even if it were conceded that the disparities in the recount processes between counties and within counties were indefensible, the equal protection analysis only demands that these anomalies be eliminated. But the equal protection critique offers no guidance as to how that should be done.

Accordingly, the appropriate remedy (at least if time is no constraint) is to remand the case to the Florida courts to decide which uniform standard should apply. At this point, Gore's prospects have to improve. The Florida Supreme Court made painfully clear that it held that the clear intention of the voter was the touchstone of Florida's election law. ${ }^{15}$ It takes little imagination to predict that, if it had been forced to adopt a uniform standard for all punchcard ballots, the Florida Supreme Court could leap to that standard that maximized the number of undervotes that were included in the final tally. It was not just chance that Broward County had produced 567 net Gore votes and Palm Beach County only around $200 .^{16}$ No one could be certain that this change in the rules of the game would have erased the slender Bush advantage, but the recent reexamination of the ballots by the Miami Herald suggests that Bush would have maintained his razorthin advantage to the bitter end, even if the ballots had been recounted under the standards enunciated by the Florida Supreme Court.

14 For an early expression of this limited ideal, see Powell $v$ Pennsylvania, 127 US 678, 687 (1888) (ruling that state regulation of oleomargarine did not violate equal protection as it subjected all in the business to the same regulations).

15 See Palm Beach County Canvassing Board v Harris, 772 S2d 1220, 1238 (Fla Nov 21, 2000), vacd and remd as, Bush v Palm Beach County Canvassing Board, 121 S Ct 471 (2000) (per curiam).

16 The extent of the differences is captured in this measure of Gore Yield prepared by Professor Jeffrey Milyo of the Harris School of Public Policy:

Gore Yield*

County

Miami-Dade:

Broward

Palm Beach

*estimated

The obvious liberalization in Miami-Dade and Broward magnified the swing.

"Gore Yield" = (net Gore votes added divided by undervotes manually counted). 
The equal protection analysis thus does nothing to halt the recount process. What is needed is some anchor that locks the Florida Supreme Court into choosing a more restrictive rule. That anchor was available in Palm Beach County where the local rule stated: "A chad that is fully attached, bearing only an indentation, should not be counted as a vote."17 Indeed, there was no evidence that any other county in Florida had ever departed from that understanding. This anchor has two advantages. The first is that it offers a litmus test to determine what counts as a valid vote: if the light shines through, then the vote can count; otherwise it does not. The second is that the uniform past practice (especially in Palm Beach) resonates with the powerful notion of fairness that holds that you cannot change the rules after the race has been run.

This last concern probably accounts for the belated and undeveloped reference to possible due process violations in the per curiam opinion. ${ }^{18}$ That maneuver runs into the potential doctrinal obstacle that a "vote" as such, notwithstanding its enormous institutional importance, may not rank as either "liberty" or "property" that is covered by the Clause. (There is no similar restriction in the Equal Protection Clause, which governs most voting cases.) Even the broad definitions of liberty and property do not explicitly cover voting rights. ${ }^{19}$ Yet on the other hand, so long as corporate shares, complete with voting rights, count as property, then it may well make sense to accept this broader reading here. Yet even this revised constitutional theory calls for a remand to the Florida courts, albeit with somewhat different instructions. Dimpled chads are out, and the Florida Supreme Court must run its recount under more restrictive rules. The U.S. Supreme Court's per curiam opinion did not pursue this issue further, but it segues neatly into the Article II issue to which I shall now turn.

17 Guidelines on Ballots with Chads Not Completely Removed, Adopted by the November 6,1990 Canvassing Board.

18 Bush v Gore, $121 \mathrm{~S} \mathrm{Ct}$ at 532.

19 See, for example, Meyer v Nebraska, 262 US 390 (1923). The Court described its conception of liberty:

While this Court has not attempted to define with exactness the liberty thus guaranteed, the term has received much consideration and some of the included things have been definitely stated. Without doubt, it denotes not merely freedom from bodily restraint but also the right of the individual to contract, to engage in any of the common occupations of life, to acquire useful knowledge, to marry, establish a home and bring up children, to worship God according to the dictates of his own conscience, and generally to enjoy those privileges long recognized at common law as essential to the orderly pursuit of happiness by free men.

Id at 399. Those privileges generally did not include the right to vote. Likewise the right to vote has not been included in the expanded list of property interests that have been protected under the Due Process Clause. See, for example, Goldberg v Kelly, 397 US 254, 260-64 (1970) (using a definition of property rights expansive enough to include the statutory right to welfare benefits). 


\section{WHAT DID THE FLORIDA LEGISLATURE DIRECT?}

To the best of my knowledge no case, prior to Bush v Gore, had passed on the proper interpretation of the Article II, Section 1, Clause 2 requirement that Florida shall "appoint" its presidential electors "In such Manner as the [Florida] Legislature [ ] May Direct." That question presumptively gives rise to many interpretive difficulties that were not raised in this case. To mention just two, it is not clear whether this provision requires that the "manner" for choosing electors be settled before the election or whether it allows Florida to change its mind after a popular election has been held but before the Electoral College meets. It would, to say the least, be very disconcerting to know that the Republican legislature could have voted to ignore the results of the popular vote if Gore had carried the state by one million votes. And if it could not intervene in that case, then could it intervene when the popular vote is much closer?

For our purposes, however, these difficulties can be mercifully skirted, because the root of the sensible challenge to the decisions of the Florida Supreme Court rests on the argument that the litigation phase of this election was not carried out in accordance with the substantive or procedural provisions of Florida's election law. To make this argument successfully, it is necessary to surmount some major pitfalls. Anyone who looks at this statute knows that it, like all complex legislation, calls out for interpretation. Even though the responsibility for interpretation is squarely given to the Secretary of State under the $\mathrm{Act}^{21}$ at some level, this task falls into the province of the courts. It must therefore be shown, for there to be a violation of Article II, Section 1, Clause 2, that the state court's interpretation does not fall within the boundaries of acceptable interpretation, but rather represents what must be termed, for want of a better term, a gross deviation from the scheme outlined in the statute. It should not be assumed, however, that this standard means that gross deviations from the legislative scheme can never be found so long as there are latent inconsistencies within the statutory framework. The courts may rightly query whether or not magenta counts as red, but they cannot do the same

20 This provision should be read in conjunction with Article I, $\S 4, \mathrm{cl} 1$ : "The Times, Places and Manner of holding Elections for Senators and Representatives, shall be prescribed in each State by the Legislature thereof; but the Congress may at any time by Law make or alter such Regulations, except as to the Places of chusing Senators." The most obvious contrast is that between "holding" elections and "appointing" electors. Does this preclude the use of popular elections to "appoint" electoral slates for the presidency? Even if it does not, it seems that parallel concerns with federal judicial oversight in particular elections would apply here if the manner in which an election is held deviates substantially from the legislative plan.

21 See Fla Stat Ann $\$ 97.012$, reproduced partially in text accompanying note 8 . 
for green. Stated otherwise, the Florida Supreme Court can choose either $A$ or $B$ when both are plausible readings, but cannot choose $C$, which differs from both $A$ and $B$, simply because it cannot decide between $A$ and $B$. The size of the ambiguity limits the scope of judicial discretion.

Second, it does not appear that any gross deviation from the Florida statutory scheme must be intentional. Article II, Section 1, Clause 2 reads like a strict liability provision. The Florida legislature directs the manner in which the presidential electors are appointed, and all other actors within the Florida system have to stay within the confines of that directive. The word "direct" is a strong term whose sense is captured in the phrase "directed verdict," which refuses to let a jury stray beyond the area of permissible inferences. ${ }^{22}$ It is not necessary that one allege or establish systematic bad faith on the part of the Florida Supreme Court to make the charge stick. It is only necessary to show that the gross deviation has in fact taken place.

Third, this dispute is not governed by the usual rule that gives state courts the last word on the interpretation of state law. That rule makes perfectly good sense when the matter in question is one that states regulate by virtue of their status as independent sovereigns within a federal system. But in this case, the strong federal interest in the selection of the President of the United States makes it appropriate for federal courts to see that all state actors stay within the original constitutional scheme. Given judicial review, the United States Supreme Court has the last word on whether any state has strayed from its constitutional path in choosing its presidential electors. Surely, it would raise a federal question if the Secretary of State decided, contrary to state statutes, to ignore the state election returns in authorizing the slate of state electors even if the state courts remained silent. If therefore the state courts or state executive officials have failed properly to apply the state scheme, resulting in a gross deviation from the legislature's directives, then a federal court can review the matter under Article II.

Fourth, resort to Article II eliminates all doubts over the remedial fit that plagues the Court's equal protection argument. Once it is determined that the Florida Supreme Court has strayed from the legislative scheme, then the United States Supreme Court has no obligation to remand the case for another round. Rather, it becomes perfectly sensible to let the Secretary of State's determination stand since the Gore forces had not made any viable challenge to it.

22 See, for example, Quinton v Farmland Industries, Inc, 928 F2d 335, 338-39 (10th Cir 1991) (noting that a directed verdict is appropriate when "the evidence and permissible inferences therefrom indicate that reasonable minds could not differ") (emphasis added). 
With these preliminaries out of the way, it now becomes possible to identify some of the key mistakes of the Florida Supreme Court that support the charge that it created its own electoral scheme that substituted judicial authority for that of the Secretary of State. As an overarching objective, the main mission of the election law is to expand the franchise so that all eligible voters who choose to exercise their rights have a reliable means to do so. But an election code has to contend with grubby realities as well as lofty aspirations. Hence it must reconcile the desire for inclusion with the twin interests of finality and probity. Elections must be decided quickly enough so that the winners can prepare to assume public office. And the rules governing elections must be tight enough to prevent the use of fraudulent practices-before, during, and after an election - that might alter an outcome of an election for the worse. The key element in reading the Florida Election Code therefore is to see how these three concerns work themselves out in connection with particular statutory provisions. In this case it is instructive to look at three particular points. The first of these concerns the definition of what counts as an "error in the vote tabulation." which the local canvassing boards had to submit their tallies to the Secretary of State. The third element concerns the relationship between the (initial) protest phase of the proceedings and the (subsequent) contest phase. On each of these points, the Florida Supreme Court turned the original electoral system, as directed by the legislature, on its head.

\section{A. Errors in Tabulation}

The first question of note involves the conditions that must be satisfied in order to have the hand recount that Gore requested. Here the basic statutory provision states that if the manual recount indicates an "error in the vote tabulation which could affect the outcome of the election, the county canvassing board shall:

(a) Correct the error and recount the remaining precincts with the vote tabulation system;

(b) Request the Department of State to verify the tabulation software; or

(c) Manually recount all ballots." 
The entire recount procedure is thus predicated on a determination of an error in vote tabulation. Unless that is shown, no hand recount is authorized at all. In dealing with this issue, the administrative interpretation given to that phrase was that an "error in the vote' tabulation only means a counting error resulting from incorrect election parameters or an error in the vote tabulating software." ${ }^{25}$ The Florida Supreme Court also recognized, in line with federal principles on this same subject, ${ }^{26}$ that it was bound to follow the interpretation that the Division of Elections gave (which the Secretary of State followed) to this phrase unless it constituted clear error, which it promptly found:

The plain language of section $102.166(5)$ refers to an error in the vote tabulation rather than the vote tabulation system. On its face, the statute does not include any words of limitation; rather, it provides a remedy for any type of mistake made in tabulating ballots. The Legislature has utilized the phrase "vote tabulation system" and "automatic tabulating equipment" in section 102.166 when it intended to refer to the voting system rather than the vote count. Equating "vote tabulation" with "vote tabulation system" obliterates the distinction created in section 102.166 by the Legislature. ${ }^{27}$

This logic counts as pure sophistry, not plain meaning. The Florida Supreme Court drew a vacuous distinction between a vote tabulation and a vote tabulation system, without explaining why it matters in this case. At no point did it bother to offer any account as to the meaning of the term "tabulation" as it appears in both phrases. The clear sense of this term is captured in its dictionary definitions, which refer to the organization of data in tables or other accessible form. ${ }^{28}$ That is exactly what the Secretary of State claimed. Her view allowed corrections to the extent that there were errors in addition and compilation; it also allowed correction to the extent that the tabulation system operated defectively so as to generate the wrong results. There is therefore perfectly good reason to use the phrase "automatic tabulat-

25 Palm Beach County Canvassing Board v Harris, 772 \$2d 1220, 1229 (Fla Nov 21, 2000) (citing with disapproval the conclusion of the Division of Elections), vacd and remd as, Bush v Palm Beach County Canvassing Board, 121 S Ct 471 (2000) (per curiam).

26 See, for example, Chevron, USA, Inc v Natural Resources Defense Council, Inc, 467 US 837,866 (1984) (ruling that federal courts must defer to an administrative agency's reasonable interpretation of an ambiguous statute).

27 Palm Beach County Canvassing Board v Harris, 772 S2d at 1229.

28 See, for example, the definition offered in Merriam-Webster's Collegiate Dictionary 1199 (10th ed 1993) ("tabulate 1 : to put into tabular form 2 : to count, record, or list systematically." "tabular ...2 a : of, relating to, or arranged in a table; specif: to set up in rows and columns b : computed by means of a table."). 
ing equipment" in some portions of the statute but not in others. But there is absolutely nothing in this provision that expands the word "tabulating" so that the statute "provides a remedy for any type of mistake made in tabulating ballots"-where the word tabulating no longer has its original restrictive meaning, but now covers the separate issue of standards: What counts as a valid vote?

The same point can be fortified when one looks at the three alternative remedies that are allowed once the canvassing board finds an error in tabulation. The first is that the errors that have been detected can be corrected. The remainder of the precincts can then be counted with the vote tabulation system in place. ${ }^{29}$ It seems quite clear that the remedy in no way opens up the definitional question of what counts as a valid vote because the recount relies on the same machine reading used in the original counting process. The second remedy is again focused on how the mechanical task of counting could have gone awry, for it allows the canvassing board to ask the Department of State to verify the tabulation software. ${ }^{30}$ This remedy does nothing whatsoever to change the initial definition of what counts as a valid vote. Its sole purpose is to debug the equipment used to tally votes.

All the action therefore swirls around the third option, which allows the canvassing board, if it chooses, to recount all the ballots manually." The conjunction that separates alternative (b) from alternative (c) is "or," and this suggests that the choice of remedies lies within the sound discretion of the canvassing board, as the Florida Supreme Court itself recognized. It defies comprehension, however, that the local canvassing board should have the power to make or break any candidate based simply on its choice among these three remedial options. The obvious structure of the entire provision is that the three remedies are in pari materia. They are all directed toward the same end-the correction of errors in tabulation that arise from either human or machine error. That program can be implemented only if the definition of a properly cast ballot does not vary with the method the canvassing board chooses to rectify the error in tabulation. On this view, the sole function of the hand recount is to examine ballots to see whether they meet the standards for a ballot that is machine readable.

At this point, the functions of the hand recount should be limited to two kinds of situations. The first is whether the chad has been so al-

29 See Fla Stat Ann $\$ 102.166(5)(a)$.

30 See id $\$ 102.166(5)$ (b).

31 See id $\S 102.166(5)$ (c).

32 Palm Beach County Canvassing Board v Harris, 772 S2d at 1229. 
tered that it allows the passage of light through the opening. This test does not count dimpled chads, but counts partially hanging chads that have been displaced sufficiently to allow the light to shine throughthe implicit requirement in the 1990 Palm Beach rule. ${ }^{33}$ This test might have also been stretched (as had never been the case in Florida) to count some dimples on evidence of equipment malfunction that prevented the stylus from working - of which it appears that there was none. ${ }^{34} \mathrm{~A}$ minimum condition for that approach is for the dimples to appear in a consistent fashion across the face of the ballot in which few, if any, of the chads are punched clear through. Under these circumstances, the argument can be made that the equipment failed to register votes whose intention can be discerned from the pattern of dimples that replicate the outcomes that are found in ballots that have been cleanly punched. But, to repeat, this conclusion is far from selfevident in the absence of some evidence of any systemwide failure of the ballot equipment. It is therefore a close question as to whether these "definite dimples in a coherent pattern" should count as errors in tabulation.

It is at this point that the distribution of powers between the Secretary of State, with her statutory responsibility for "interpretation" of the election law, ${ }^{35}$ and the Florida Supreme Court comes into tension. Both the meaning of "tabulating" as well as the structure of the statute's remedial provisions wholly undermine the claim of the Florida Supreme Court that "the plain meaning" of the statute is such to allow a hand recount to take place under conditions in which dimples shall count, or at least be "considered," no matter what the condition of the voting machinery. The opposite conclusion more accurately captures the sense of the law. It thus counts as clear error to authorize the local canvassing boards to use a manual recount to remedy an "error in vote tabulation" as a pretext for adopting a broader definition of what counts as a valid vote. That decision belongs to the Secretary of State in her oversight function, not to the local canvassing boards, and not to the Florida courts.

The Florida Supreme Court sought to overcome the weight of the statutory language by noting the importance of guarding against error:

Although error cannot be completely eliminated in any tabulation of the ballots, our society has not yet gone so far as to place blind faith in machines. In almost all endeavors, including elec-

33 Guidelines on Ballots with Chads Not Completely Removed (cited in note 17).

34 See Gore v Harris, 2000 WL 1790621, *3 (Fla Cir Ct Dec 3) (Sauls) (notice the lack of evidence of irregularity), revd and remd as Gore v Harris, 772 S2d 1243 (Fla Dec 8, 2000), revd as Bush v Gore, $121 \mathrm{~S} \mathrm{Ct} 525$.

35 See Fla Stat Ann $\$ 97.012$. 
tions, humans routinely correct the errors of machines. For this very reason Florida law provides a human check on both the malfunction of tabulation equipment and error in failing to accurately count the ballots.

But once again this represents a complete misapprehension of how voting laws, and machines, work in Florida and elsewhere. The reason we have machine counts is to guard against the risk of human error and bias. The Florida Court thus wholly misstates the basic position by blithely assuming that it is possible to correct one type of error without introducing a second kind of error. The restricted types of review noted above constitute a sensible effort to take both human and machine error into account, and to guard against the possibility that zealous supporters of a given candidate or cause will invent votes where none exist. ${ }^{37}$ A litmus test is not an impediment to justice but a bulwark against fraud. Watching election judges with political connections search for scratch marks on ballots is a somber reminder that both kinds of error exist.

This reticence to rely on dimples is, moreover, ironically supported by the Illinois Supreme Court decision in Pullen $v$ Mulligan, which the Florida Supreme Court cited to support its own expansive views. In Pullen the Illinois Supreme Court wrote:

To invalidate a ballot which clearly reflects the voter's intent, simply because a machine cannot read it, would subordinate substance to form and promote the means at the expense of the end.

The voters here did everything which the Election Code requires when they punched the appropriate chad with the stylus. These voters should not be disfranchised where their intent may be ascertained with reasonable certainty, simply because the chad they punched did not completely dislodge from the ballot. Such a failure may be attributable to the fault of the election authorities, for failing to provide properly perforated paper, or it may be the result of the voter's disability or inadvertence. Whatever the reason, where the intention of the voter can be fairly and satisfactorily ascertained, that intention should be given effect. ${ }^{39}$

36 Palm Beach County Canvassing Board v Harris, 772 S2d at 1229-30.

37 On the risks, see Philip R. O'Connor, Democrats Hand-Count Gamble Un-American, Chi Trib 23 (Nov 22, 2000) (noting the risk of human bias: "Machines don't have agendas. Humans do. Machines are honest.").

38138 Ill 2d 21, 561 NE2d 585 (1990).

39 Id at 611 (emphasis added) (citations omitted). "Did not completely" means "partially." 
As a subsequent story in the Chicago Tribune reports, ${ }^{40}$ this rhetoric did not cash out as a license for local boards to use whatever standards they chose in running the hand count. Rather, the hand count was done by shining lights through the ballot to see whether a human eye could pick up a beam of light that the machine might have missed. ${ }^{41}$ Dimples, even definite dimples, were not counted, doubtless because of the risk of fraud and abuse of discretion that such a nebulous standard introduces. To my knowledge, there has never been an election in Florida in which dimples were counted as votes, given the need for some objective verification of the intention of a voter who can testify as to what he or she meant. On the merits therefore the Secretary of State relied on a far sounder interpretation of Florida law than did the Florida Supreme Court. If so, then the Florida Supreme Court abused its discretion in overriding the interpretation on which she relied with its own.

\section{B. The Cutoff Date}

The second bone of contention in the first Florida Supreme Court case was whether the Secretary of State had discretion not to accept tallies from the various counties more than a week after the election. As a matter of administrative prudence, I think that it is clear that she made the wrong choice in cutting off the recount so precipitously. What she should have done in my view was to extend the period for the count while insisting on a standard of interpretation that precluded the use of the dimples, which was well within her discretion. But be that as it may, the question here is not whether she made the best possible choice, but whether she acted within the limits of her delegated powers. On this point the two key statutory provisions leave much to be desired. Section 102.111, which deals with the position of the Elections Canvassing Commission, provides:

If the county returns are not received by the Department of State by 5 p.m. of the seventh day following an election, all missing counties shall be ignored, and the results shown by the returns on file shall be certified. ${ }^{42}$

40 Jan Crawford Greenburg and Dan Mihalopoulos, Bush Turns to Top U.S. Court: Republican Wants Florida's Manual Recount Stopped: Illinois Case Offers Shaky Precedent, Chi Trib 1 (Nov 23, 2000) (noting that "the Illinois court actually affirmed a trial judge's order to exclude dented ballots, since he had decided he could not reasonably determine the voters' will by examining the ballots").

41 "[Circuit Court Judge Francis] Barth counted most of the ballots that had been perforated enough for light to shine through them, even if the paper tag known as a chad had not fallen out." Id.

42 Fla Stat Ann § 102.111(1) (West 2000) (emphasis added). 
Thereafter Section 102.112 picks up the thread under the heading "Deadline for submission of county returns to the Department of State; penalties." It provides:

If the returns are not received by the department by the time specified, such returns may be ignored and the results on file at that time may be certified by the department. ${ }^{43}$

As the italicized words make clear, no one can doubt the conflict between these two sections. Section 102.111 is badly drafted because it seems to direct that all returns shall, in other words, must, be ignored if they are submitted after the seven-day period: nothing can be done to resurrect them. But if the returns are a dead letter, then it makes no sense to say in the next section that the Secretary of State may ignore them: for if she may ignore them, then she may also take them into account. In addition, to read the "shall" in Section 102.111 to control the "may" in Section 102.112 renders otiose and superfluous the penalties that the Secretary of State is empowered to impose on tardy local canvassing officials.

It is therefore incumbent to make some adjustment in the statutory language for the provisions to harmonize with each other. Truth be known that is not difficult to do. All that is required is to read the "shall" language so that it does not refer to the status of the late returns, but to the duty of the canvassing boards. The provision works, as it were, in personam and not in rem. The local canvassing officials are under a duty to submit the returns within the week under Section 102.111, but the Secretary of State has the power to extend that deadline if she so chooses, under, of course, the usual abuse of discretion standard that governs administrative officers generally. The upshot is that the local boards have a week to conduct a recount - no questions asked. But once they wish to go beyond that, then they must persuade the Secretary of State, who oversees the statewide process, to agree.

Unfortunately, at no point does the Florida Supreme Court acknowledge this obvious way to break the impasse. Instead it trots out every conceivable canon of statutory interpretation to

conclude that, consistent with the Florida election scheme, the Secretary may reject a Board's amended returns only if the returns are submitted so late that their inclusion will preclude a candidate from contesting the certification or preclude Florida's voters from participating fully in the federal electoral process.

43 Id § 102.112(1) (emphasis added). 
The Secretary in the present case has made no claim that either of these conditions apply at this point in time. ${ }^{44}$

This order has no textual base whatsoever and it bears no relationship to either of the two sections that spawned the conflict in the first place. Surely, the Florida Supreme Court could not have defended its reading if Section 102.111 had been drafted to say, "The Canvassing Boards are under a Duty to Submit Returns within one week after the election unless this obligation is waived by the Secretary of State." By going far afield, the Florida Supreme Court invents its own standard that takes all the discretion away from the Secretary of State and puts her in a position where she must accept hand recounts completed after the statutory cutoff date so long as it remains possible to raise a contest, which is itself an odd rule given the inherent uncertainty over how long that contest might last. Yet even after this raw assumption of power, the court went further, taking it upon itself to determine when the protest phase of the electoral challenge is over. Here the Florida Supreme Court holds that it "must invoke the equitable powers of this Court to fashion a remedy that will allow a fair and expeditious resolution of the questions presented here." ${ }^{45}$ The bottom line was 5:00 p.m. on Sunday, November 26, 2000. But this assertion of "equitable jurisdiction" has no textual referent: it looks like a fig leaf for judicial legislation, pure and simple.

In stressing this point, it is critical to note that "equitable jurisdiction" is not some formless field that gives all courts an implicit license to do as they please. ${ }^{46}$ Traditionally, cases of equitable jurisdiction have been defined by the remedy afforded: damages were the province of the common law; specific performance, injunctions, foreclosure, and the like were equitable remedies that historically set out the scope of the Chancellor's jurisdiction. There is no question that equitable remedies could often be flexible; multiple parties were often involved, and remedies that operated on a defendant had to take into account their interests. ${ }^{47}$ But by the same token equitable jurisdiction has never left courts with unchartered discretion to do what they choose: rather, it was constrained by its own set of rules, and I am aware of no general principle of equity that would allow a court to ride roughshod over a

44 Palm Beach County Canvassing Board v Harris, 772 S2d 1220, 1239 (Fla Nov 21, 2000), vacd and remd as, Bush v Palm Beach County Canvassing Board, 121 S Ct 471 (2000) (per curiam).

45 Palm Beach County Canvassing Board v Harris, 772 S2d at 1240.

46 For the general principle, see Albemarle Paper Co v Moody, 422 US 405, 416-17 (1975) ("That the court's discretion is equitable in nature hardly means that it is unfettered by meaningful standards or shielded from thorough appellate review.") (citations omitted).

47 For a general discussion, see F.W. Maitland, Equity: A Course of Lectures (Cambridge 2d ed 1949) (revised by John Brunyate), in particular Lectures 1 and 2 (discussing the history and nature of courts of equity, particularly in England). 
particular time limitation contained in a statute in favor of its own alternative date. ${ }^{48}$ This is not a case where a court of equity invokes a principle of laches for an equitable cause of action in the absence of any specific time limitation. Nor is it even a case in which statutes of limitations are tolled to take into account specific disabilities of particular plaintiffs.

The reliance on equitable jurisdiction is a fig leaf, pure and simple, which allowed the Florida Supreme Court to impose its will on a Secretary of State who thought otherwise. The transfer of this power of discretion counts as arrogation by the judicial branch of powers reserved to the executive branch by statute. Had her decision been respected, the protest phase of this case would have ended as of November 14, 2000, and, as will become clear, her orders would have been immune from challenge. It makes good sense for the United States Supreme Court to enforce the result as of that date as the outcome that the legislature, by its articulation of general rules and its vesting of discretion in the Secretary of State, had directed.

\section{Protest versus Contest}

The last feature of the Florida decisions that requires some comment concerns the relationship between the protest and contest phases of an election dispute. The protest phase, which has already been discussed, is directed toward the selection of administrative remedies prior to the certification of the election result by the Secretary of State. These remedies operate in much the same fashion as the initial administrative conduct of the election. ${ }^{49}$ The contest phase begins only after the protest phase is over. Under Florida law the grounds for a contest after certification cover, in addition to issues of fraud, bribery, and eligibility, these two heads:

(c) Receipt of a number of illegal votes or rejection of a number of legal votes sufficient to change or place in doubt the result of the election.

48 See, for example, Cope $v$ Anderson, 331 US 461, 463-64 (1947) (noting that the same statute of limitations applies to legal and equitable remedies for the same underlying wrong). For a more general discussion, see Douglas Laycock, Modern American Remedies: Cases and Materials 931-34 (Little, Brown 2d ed 1994) (discussing interrelation between statutes of limitation and laches).

49 The rules are contained in Fla Stat Ann $\S 102.168$ (West 2000), enacted in 2000. The detailed rules governing these election contests are set out in Gore v Harris, 772 S2d 1243, 1253 n 4 (Fla Dec 8, 2000), revd and remd as, Bush v Gore, $121 \mathrm{~S} \mathrm{Ct} 525$. 
(e) Any other cause or allegation which, if sustained, would show that a person other than the successful candidate was the person duly nominated or elected to the office in question or that the outcome of the election on a question submitted by referendum was contrary to the result declared by the canvassing board or election board.

Once some violation of the statute has been found, the statute provides:

(8) The circuit judge to whom the contest is presented may fashion such orders as he or she deems necessary to ensure that each allegation in the complaint is investigated, examined, or checked, to prevent or correct any alleged wrong, and to provide any relief appropriate under such circumstances.

Two features about the contest phase deserve immediate attention. The first is that one has contests about protests, so that the issues raised at the second phase are efforts to overturn incorrect decisions at the protest phase. It makes no sense to read the statute as though the contest phase is wholly unconnected with anything that went on at the protest stage. If so, then there is no need to bother to wait until the protest is over for the contest to begin. The second key feature is that the statute contemplates a judicial trial, not administrative action, at the contest phase. The minimum due process requirements of a trial in turn make it imperative that each party have the chance to raise the issues that it thinks appropriate, to present evidence to advance that contention, and to rebut contentions and evidence presented by the other side. Any sensible reading of the Florida statute seems to require that these elements be observed. The broad power of the circuit judge to issue orders that "each allegation in the complaint [be] investigated, examined, or checked, to prevent or correct any alleged wrong," surely means to give a broad scope to discovery in cases of this sort. But these provisions do not do away with the other elements of a trial, including the orderly presentation of evidence, under the usual rules of admissibility and cross-examination, before the court for its decision.

The order issued by the Florida Supreme Court did nothing to respect either of these key structural features about the relationship between these two phases of an integrated process. The threshold issue in its deliberation was to determine the standard of review that should be used during the contest phase. The statute itself is silent on the 
standard of review that the circuit court in an election contest should apply to the administrative results of the protest phase. Yet the Florida case law has read Florida law as calling for the abuse of discretion standard that Judge Sauls had applied, most recently in its first foray into this dispute.

The internal logic of the Florida statute strongly confirms that this review should be done, as is the case with other administrative actions, under an abuse of discretion standard. After all, the initial statute gives the canvassing board the initial choice over the method that it wishes to use to correct errors in tabulation brought to light in the protest phase. Indeed in its first decision, the Florida Supreme Court stressed the word "or" in the choice of remedies. It seems odd in the extreme to reverse fields and now hold that the original protest was little more than a preliminary canter, so that the disappointed party can relitigate on demand in the contest phase all matters in the case solely on the assertion that the undervote had not been properly counted.

Once it chose the de novo review standard, the Florida Supreme Court simply took over the entire administration of the election challenge, trespassing on the functions allocated to either the canvassing boards or the Secretary of State. Thus the Florida Supreme Court took it upon itself to order a statewide recount of the undervote (but not the overvote) ${ }^{54}$ Yet it nowhere explained where it received the power to make (as an appellate court no less) an order that neither side had requested. In support of its decision, it emphasized the words "investigated, examined, or checked," and it acted as though the prior referent to the "each allegation contained in the complaint" did not limit their scope. ${ }^{5 s}$ Trials do not allow an appellate court to set for itself the parameters of the initial complaint, and neither Gore nor Bush asked for a statewide recount. The Florida Supreme Court made a unilateral decision to order a statewide recount, which flies in the face of the structure of the statute, which conducts protests on a county-by-county level only, and which leaves it to the parties to determine the scope of any contest that they might wish to raise if they are disappointed with

53 See Broward County Canvassing Board v Hogan, 607 S2d 508, 510 (Fla Dist Ct App 1992) (ruling that county canvassing boards had discretion to order or not to order a hand recount), quoted in Gore v Harris, 772 S2d at 1265 (Wells dissenting):

\footnotetext{
Although section 102.168 grants the right of contest, it does not change the discretionary aspect of the review procedures outlined in section 102.166 . The statute clearly leaves the decision whether or not to hold a manual recount of the votes as a matter to be decided within the discretion of the canvassing board.
}

54 Gore v Harris, 772 S2d at 1262.

55 Id at 1261. 
the outcome of the protest phase. It is hard to see how any remedy that goes beyond the boundaries of the complaint could count as "appropriate" for a judicial proceeding, even if the other requisites for a full-fledged contest had been satisfied, which, as noted above, they were not.

In order to secure this result, the Florida Court did not give due weight to the statutory words "rejection" and "legal." It wrote

that a legal vote is one in which there is a "clear indication of the intent of the voter." We next address whether the term "rejection" used in section 102.168(3)(c) includes instances where the County Canvassing Board has not counted legal votes. Looking at the statutory scheme as a whole, it appears that the term "rejected" does encompass votes that may exist but have not been counted. ${ }^{56}$

This reading makes it appear as though voter failure is tantamount to official misconduct. As Chief Justice Rehnquist wrote, "Florida statutory law cannot reasonably be thought to require the counting of improperly marked ballots." ${ }^{57}$ If the Florida legislature wanted to make the failure to ascertain the intention of the voter the standard for triggering a contest, it could have done so in just those words. But what it did do was to treat the exclusion of legally-cast ballots on a par with the inclusion of illegal ballots (for example, prisoner votes). A more sensible reading indicates that this provision is directed at local election officials who rejected, that is refused to accept or to count, votes that were properly cast. The image connoted is a blockade of legal voters from the polls. The paired use of the terms "legal" and "illegal" is designed to catch cases of misconduct of electoral officials, which is just not involved here. The section reads on a par with the provisions that allow contests over the question of candidate eligibility, fraud, and bribery. ${ }^{58}$ It does not invite any decision not to count those ballots that do not meet the standards for validity that were set out in the election procedures themselves and then communicated clearly to voters.

In sum, then, Chief Justice Rehnquist draws blood when he writes: "It is inconceivable that what constitutes a vote that must be counted under the 'error in the vote tabulation' language of the protest phase is different from what constitutes a vote that must be counted under the 'legal votes' language of the contest phase." ${ }^{, 59}$ The two sections cannot be read to use standards that are in flat contradiction with each other. Nor is the situation salvaged by appealing to Sec- 
tion $102.168(\mathrm{e})$, for the cause to be shown can only be the failure to adopt a broader definition of a countable ballot than that applicable in the protest phase, which makes no more sense here than it does with Section 102.168(e). Unfortunately, the Florida Supreme Court, once again, was happy to proceed simply on a showing that dimples were not counted on ballots somewhere inside the state, wholly without any showing of machine failure or electoral irregularity. ${ }^{60}$

This illicit expansion of the statutory grounds for a contest seems pretty clear. What is worse is that the maneuver wholly precludes the articulation of any coherent grounds to relate the protest to the contest provisions, even though the statutory scheme contemplates that the contest should be to review the protest stage, and commence within five days after it is finished. ${ }^{61}$ But the difference matters. Given that an election contest is a trial, the Florida Supreme Court cannot simply conclude without a trial that the Broward County manual recount was correctly done. If it is appropriate in a de novo proceeding (assuming that was allowed under the statute) to count votes that have not been punched as required, then that de novo review cannot be selectively invoked, but must apply to all phases of the case. It is therefore wholly improper at the contest phase not to allow Bush to move-or indeed to raise the issue on its own motion-to exclude dimpled ballots on the grounds that they manifested no clear intention at all. The dual standard is not acceptable. The pro-Bush findings by the local canvassing boards were subject to de novo review. The pro-Gore findings were treated as res judicata.

The utter lack of any sense of continuity between protest and contest was only magnified by the Florida Supreme Court's treatment of the Miami-Dade decision not to continue the recount of the undervote when it decided that it could not do so accurately before the November 26, 2000, deadline set by the Florida Supreme Court. The entire thrust of the first Florida Supreme Court decision was to hold that the discretion in the protest phase rested with the canvassing boards even after the seven-day deadline of November 14, 2000, had passed. But once this Canvassing Board decided that it could not recount all the ballots (as Section 102.166(5)(c) required), then its discretion vanished in favor of an obligation to recount all ballots even after the

60 This point is repeatedly stressed in the dissent of Wells, C.J., see Gore v Harris, 772 S2d at $1263-64$.

61 A party that wants to raise a contest must file a complaint "within 5 days after midnight of the date the last county canvassing board empowered to canvass the returns certifies the results of that particular election following a protest pursuant to s. 102.166(1)." Fla Stat Ann $\S 102.168(2)$, relied on in Gore v Harris, 772 S2d at 1270 (Wells dissenting). 
court-imposed November 26, 2000, deadline. ${ }^{62}$ That overlap in processes makes it quite clear that what happens here is not an orderly progression between protest and contest, where the grounds of the contest are necessarily more limited than choices available in the protest stage. Rather, the entire statutory scheme is transmuted into one long recount that in the end was entrusted to the trial judge of Leon County, who was asked to assemble personnel to continue the recount on a statewide level, thereby assuming all the functions vested by statute in the Secretary of State. At this point, it seems clear that Chief Justice Rehnquist has it exactly right when he writes of the various maneuvers of the Florida Supreme Court:

Underlying the extension of the certification deadline and the shortchanging of the contest period was, presumably, the clear implication that certification was a matter of significance: The certified winner would enjoy presumptive validity, making a contest proceeding by the losing candidate an uphill battle. In its latest opinion, however, the court empties certification of virtually all legal consequence during the contest, and in doing so departs from the provisions enacted by the Florida Legislature.

\section{CONCLUSION}

In sum, there is ample reason to believe, as the Rehnquist concurrence in Bush v Gore urges, that the Florida Supreme Court adopted, under the guise of interpretation, a scheme for conducting election challenges that deviates markedly from that which the Florida legislature had set out in its statutes. I have tried to indicate the multiple ways in which the Florida Court did violence to the state statutory scheme. To many modern mainstream constitutional scholars that conclusion might seem harsh because they find it hard to accept that weighty matters of constitutional interpretation do have right, and hence wrong, answers that can be gathered from a close examination of text, structure, and function. But accepting that view of pervasive skepticism disables them from intelligent criticism of the United States Supreme Court. If, conceptually, the Florida Supreme Court could not cross an imaginary line, then neither could the United States Supreme Court. If constitutional law is politics by another name, then it makes no more sense to condemn the United States Supreme Court for its political predilections than it does to condemn the Florida Supreme Court for its. All is politics and in that world rank alone becomes the sole arbiter of truth. 
Effective criticism of the United States Supreme Court necessarily depends, then, on a view of language that allows for us to recognize that legal interpretation at any level could be wrong, indeed so wrong as to count as an abuse of discretion for partisan political ends. I think that charges of serious conceptual error do have a lot of force in dealing with the equal protection argument that five members of the United States Supreme Court found decisive. But by the same token, I hope that I have said enough to show that the alternative Article II argument has far more traction in light of what I regard to be the manifest errors in the Florida Supreme Court's decisions. Quite simply, if the canvassing boards and the Secretary of State did not abuse their discretion, then it seems as though the Florida Supreme Court abused its. And if it abused its discretion, then the United States Supreme Court did not abuse its.

Any Article II attack on the decision of the Florida Court would itself be quite unintelligible if statutory text did not limit, and limit sharply, the range of interpretive options open to a court. But so long as we can maintain the conceptual line between interpretation and legislation, then we must recognize that it is always possible for any court, at any level, to stray over that line so that its decrees can be regarded as judicial legislation. It is, to say the least, a regrettable truth that the outcome of a presidential election necessarily turns on a question of degree, by asking just how wrong is wrong enough to topple the decision of the Florida Supreme Court. But the peculiar determination to override at various times the decisions of Florida's canvassing boards, Secretary of State, and circuit court judges crosses that line.

Thus this tortured case draws to a close. It is tragic that on matters of this moment, no one can offer a mathematical demonstration of whether the mistakes of the Florida Supreme Court were large enough to constitute a gross deviation from the Florida statutory scheme, as I believe that they were. But even that uncertainty should prompt the outspoken critics of the United States Supreme Court to reign in their indignation a little bit. After all, in order to reach that conclusion, one has to think that the United States Supreme Court committed clear error in its decision. But owing to the sorry performance of the Florida Supreme Court, that conclusion cannot be maintained, which I think is why the United States Supreme Court's decision was greeted generally with widespread relief and not widespread protest. In the end it is regrettable, but true, that the all-or-nothing choice of the President of the United States could rest on what is in the end a question of degree, as so many vital questions are. Such is the way of the world, and it will not do to rail against it. 


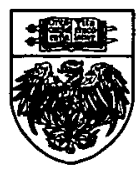

HeinOnline -- 68 U. Chi. L. Rev. 6362001 